\title{
Austempering Experiments of Production Grade Silicon Solution Strengthened Ductile Iron
}

\author{
Kaisu Soivio ${ }^{1, a}$ \\ ${ }^{1}$ Department of Mechanical Engineering, Production Engineering, Aalto University, P.O.Box 14100, \\ 00076 Aalto, Finland \\ kaisu.soivio@aalto.fi
}

Keywords: Austempered Ductile Iron, Heat Treatment, Silicon Solution Strengthening

\begin{abstract}
Austempered ductile iron provides a feasible way to produce high strength components. However, in heat treatments resulting in highest strengths some of the ductility is lost due to formation of bainitic carbides. The role of silicon in inhibiting the formation of iron carbides in ascast ductile irons as well as its solution strengthening effect is well known and acknowledged in industry. The effect of silicon on austemperability, resulting microstructures, and mechanical properties of austempered ductile irons with silicon contents with 3.4-3.8 w-\% was researched. Quenching and austempering heat treatments were carried out for production grade silicon solution strengthened ductile irons EN GJS 500-14. Results indicate, that it is possible to manufacture a fully ausferritic structure into a silicon solution strengthened matrix and indeed good ductility can be achieved in combination with ultimate tensile strength of $1600 \mathrm{MPa}$. Segregation of silicon reduces the solubility of carbon into the matrix especially close to the graphite nodules which reduce the stability of carbon stabilized austenite and leads into compromised machinability.
\end{abstract}

\section{Introduction}

Austempered Ductile Iron (ADI) is a ductile high strength engineering material with good wear resistance, fracture toughness, and fatigue strength [1]. Its properties are due to spheroidal graphite and duplex matrix structure, consisting of acicular ferrite and carbon stabilized austenite. Matrix structure is called ausferrite, although sometimes ferrite is referred as bainite or bainitic ferrite and ausferrite as carbide-free bainite. Ausferritic structure is a result of a two-step heat treatment called austempering, which is comparable to bainitising although shorter in duration due to faster transformation kinetics. Typical austempering heat treatment consists of austenitisation at $880-950{ }^{\circ} \mathrm{C}$, quenching, and isothermal hold at temperature range of $260-400{ }^{\circ} \mathrm{C}$. Adjusting the austempering temperature the phase fractions of ferrite and austenite are adjusted lower temperatures favoring strong ferrite while higher treatment temperatures increase the amount of austenite which leads into lower strength but higher ductility [2].

Solution strengthening effect of silicon on ferrite in steels was reported already in the 1960's and in as-cast ferritic ductile cast irons in 1990's [3]. Typical silicon content of approximately 2.0-2.5 wt $\%$ of ADI suppresses the formation of bainitic carbides to such extent that only at lower part of the austempering temperature range and with extended holding times at higher austempering temperatures precipitation of carbides has been observed [4]. Ausferrite is a metastable microstructure that decomposes into ferrite and bainitic carbides if held at sufficiently high temperature $\mathrm{T}_{\text {ausf }}>350{ }^{\circ} \mathrm{C}$ for long enough. At lower temperatures it has been observed that even $1000 \mathrm{~h}$ hold will not induce further austenite decomposition but carbide precipitation occurs already during parent austenite decomposition as local carbon concentration in ferrite or ferrite-austenite interface increases due slowed diffusion making precipitation of carbides thermodynamically feasible [5]. It is thus suggested, that by increasing the silicon content from the traditional levels of 2.0 to $2.5 \mathrm{wt} \%$ to those of silicon solution strengthened ferritic (SSF) ductile irons, i.e. 3.7 to $4.3 \mathrm{wt} \%$, it is possible to produce austempered ductile irons with higher strength without compromising the ductility due to formation of bainitic carbides [6]. Another application of the 
increased silicon content is the widening of the process window at higher austempering temperatures due to retarded cementite formation at longer holding times [7].

Amount of carbon in solution available for stabilizing the retained austenite in ausferritic structure is defined during austenitisation. Carbon dissolves from graphite and from pearlite if present. For SSF ductile irons graphite is only source for carbon. Silicon reduces the solubility of carbon to austenite, Voigt presented an equation, shown in Eq. 1, to estimate the influence of silicon on the carbon content of austenite as a function of austenitisation temperature [8].

$$
\% C_{p \gamma}=\frac{T_{\gamma}}{420}-0,17 * \% S i-0,95 \text {. }
$$

where $\% \mathrm{C}_{\mathrm{p} \gamma}$ is the carbon content of parent austenite in weight percent, $\mathrm{T} \gamma$ austenitisation temperature and $\% \mathrm{Si}$ silicon concentration in weight percent. This equation is based on data achieved with conventional silicon content ductile irons and austenitising temperatures. Figure 1 shows Fe-C equilibrium diagrams with $0,2,3$ and $4 \mathrm{w}-\%$ silicon calculated with ThermoCalc software. There is divergence between the presented equation and equilibrium diagrams. Previous austempering experiments with silicon solution strengthened ductile irons have used austenitising temperature of $900{ }^{\circ} \mathrm{C}$ [7, 9]. As Larker presented in his invention, high enough austenitising temperature should be used. [10] When the influence of silicon on solubility of carbon in iron and stabilities of different phases is taken into consideration and either ternary or silicon adjusted equilibrium diagrams be used, the necessity of austenitising temperatures exceeding $900{ }^{\circ} \mathrm{C}$ is clear. On the other hand, in previous research it has been shown that increased austenitisation temperature decreases ductility, impact toughness and fatigue strength in conventional ADI [8]. Extremely high austenitisation time will put stress on heat treatment facilities which are used to treat conventional ADI.

During austempering phase acicular ferrite first nucleates and then grows as carbon of parent austenite diffuses into graphite and remaining austenite. Lattice parameters are often used to determine phase carbon contents. Lattice parameters can be determined with help of x-ray diffraction analysis. Eq. 2 [11] present correlation between austenite carbon content and lattice parameter.

$$
\% C_{\gamma}=\frac{a_{\gamma}-3.573}{0.033} .
$$

where $\% \mathrm{C}_{\gamma}$ is carbon concentration and $\mathrm{a}_{\gamma}$ lattice parameter of austenite. 

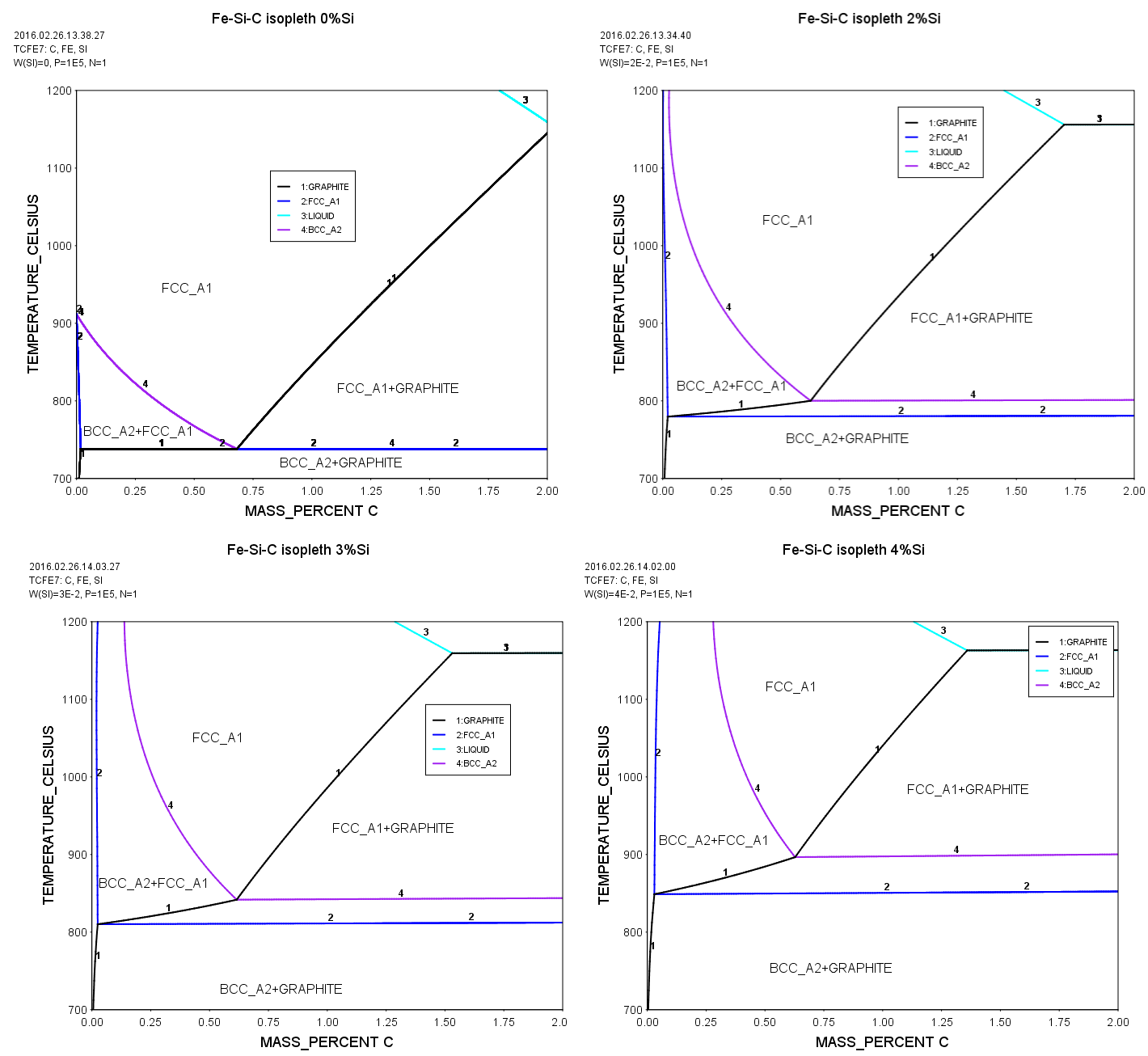

Figure 1. Fe-C equilibrium diagrams with 0, 2, 3 and 4 wt\% silicon calculated with ThermoCalc.

\section{Materials and Methods}

For the experiments a commercially produced EN GJS-500-14 melt was selected from production of a foundry. Another commercial alloy with conventional silicon content was used as a reference material, named as EN GJS-500-7. Chemical compositions of the melts are presented in Table 1. In addition to mentioned alloying elements, irons were treated with ferromagnesium alloy to provide sufficient residual magnesium content leading into spheroidal graphite with nodularity higher than $80 \%$. Experimental material was cast into different sized y-blocks. For mechanical testing $25 \mathrm{~mm}$ yblocks were used and for austemperability experiments $50 \mathrm{~mm}$ y-block was cast as raw material. Yblocks were first machined down to round $22 \mathrm{~mm}$ bars before heat treatment and in austemperability experiments $50 \mathrm{~mm}$ blocks were machined to different diameters: $25,30,35,40$ and $45 \mathrm{~mm}$ with length twice the diameter.

Table 1. Chemical compositions of the melts used as reference and in heat treatment experiments.

\begin{tabular}{|l|l|l|l|l|l|l|}
\hline Alloy & $\mathrm{C}[\mathrm{wt} \%]$ & $\mathrm{Si}[\mathrm{wt} \%]$ & $\mathrm{Mn}[\mathrm{wt} \%]$ & $\mathrm{Cu}[\mathrm{wt} \%]$ & $\mathrm{Ni}[\mathrm{wt} \%]$ & $\mathrm{Mo} \mathrm{[wt \% ]}$ \\
\hline EN GJS-500-7 & 3,69 & 2,33 & 0,4 & 0,15 & 0,03 & 0,01 \\
\hline EN GJS-500-14 & 3,25 & 3,77 & 0,24 & 0,04 & 0,06 & 0,01 \\
\hline
\end{tabular}

For mechanical testing purposes austenitisation of conventional grade ductile iron was carried out at $\mathrm{T}_{\gamma}=880{ }^{\circ} \mathrm{C}$ and SSF grade at $\mathrm{T}_{\gamma}=950{ }^{\circ} \mathrm{C}$ to gain approximately same parent austenite carbon content. Austenitisation time was held constant $t_{\gamma}=60$ minutes after furnace achieved the set temperature. Reference test sample was austempered at $\mathrm{T}_{\text {aust }}=310{ }^{\circ} \mathrm{C}$, and for $\mathrm{SSF}$ grades three 
different austempering bath temperature were used $\mathrm{T}_{\text {aust }}=270,300$ and $330{ }^{\circ} \mathrm{C}$ holding time being fixed 90 minutes. Two bars were heat treated in every temperature. Test bars were machined down to standard $14 \mathrm{~mm}$ diameter tensile test bars after heat treatment. Tensile tests were carried out in room temperature.

For austemperability experiments salt bath temperature of $300^{\circ} \mathrm{C}$ was used with same holding time of 90 minutes. Samples were cut in half from the middle for investigating the quenched depth. Samples were etched with $2 \%$ Nital to observe the first initiation of the non-ausferritic structures. Depth of the occurrence of non-ausferritic structure was determined from microstructure image series taken with optical microscope.

Ground and polished cross-sections of tensile test bars were investigated with scanning electron microscopy. Investigations were conducted with Tescan VEGA3 LMU microscope equipped with ThermoScientific energy dispersive spectroscopy (EDS) analysator.

$\mathrm{X}$-ray diffraction (XRD) studies were completed on sample prepared from one tensile test sample per austempering heat treatment temperature to measure phase fraction, lattice constants. Rikagu Smartlab diffractometer was used with $5.4 \mathrm{~kW}$ Co X-ray source. Measurement was carried out $2 \theta$ ange range $40-130^{\circ}$. An average of 16 scans with sample normal varied by 5 degrees together with oscillating rotation along the surface normal was used in order to minimize the effect of texture on intensities and increase the signal-to-noise ratio. ICDD database from 2016 was used for phase identification. For quantitative analysis Rietfeld analysis using PDXL2 software was applied. Split-pseudo-Voigt function was implemented to get good line shape for samples treated in 270 and 300 degrees but for sample treated in $330{ }^{\circ} \mathrm{C}$ Split-Pearson function gave better agreement with data.

\section{Results}

Results of tensile tests are presented in Table 2 for reference material and experimental material. Results show high strength and good ductility and small deviation between samples treated at same temperature.

Table 2. Results of tensile testing.

\begin{tabular}{|l|c|c|c|c|}
\hline Material & $\begin{array}{c}\mathrm{T}_{\text {aust }} \\
{\left[{ }^{\circ} \mathrm{C}\right]}\end{array}$ & $\begin{array}{c}\mathrm{YS} \\
{[\mathrm{MPa}]}\end{array}$ & $\begin{array}{c}\text { UTS } \\
{[\mathrm{MPa}]}\end{array}$ & $\begin{array}{c}\mathrm{A} \\
{[\%]}\end{array}$ \\
\hline GJS 500-7 & 310 & 793 & 1074 & 13,0 \\
\hline GJS 500-7 & 310 & 828 & 1098 & 14,6 \\
\hline GJS 500-14 & 270 & 1162 & 1578 & 4,0 \\
\hline GJS 500-14 & 270 & 1135 & 1548 & 4,0 \\
\hline GJS 500-14 & 300 & 1134 & 1475 & 8,0 \\
\hline GJS 500-14 & 300 & 1152 & 1491 & 7,5 \\
\hline GJS 500-14 & 330 & 986 & 1298 & 6,0 \\
\hline GJS 500-14 & 330 & 975 & 1283 & 6,0 \\
\hline
\end{tabular}

In hardenability experiments with samples quenched from austenitisation furnace to salt bath first non-ausferritic phase was pearlite despite high silicon content and as-cast ferritic structure. Samples with diameters 25 and $30 \mathrm{~mm}$ were fully ausferritic through whole cross-section but $35 \mathrm{~mm}$ bar started showing pearlite at $7 \mathrm{~mm}$ depth, Figure 2 . 


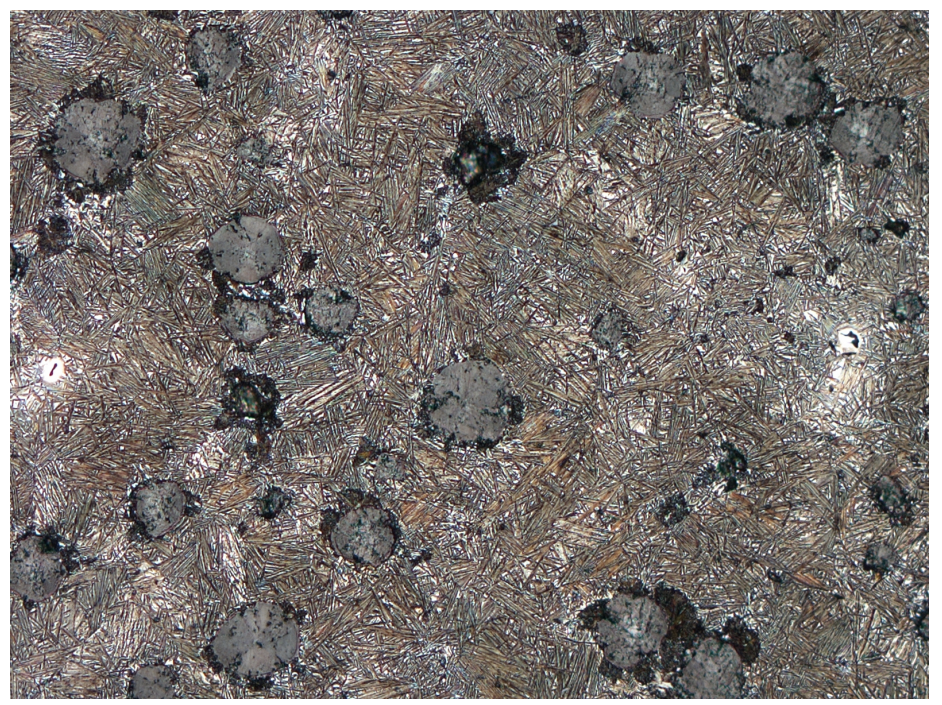

Figure 2. Nital etched microstructure of austempered $35 \mathrm{~mm}$ diameter bar cross-section. Microstructure is showing lighter brown ausferrite and darker brown pearlite around graphite nodules at depth of $7 \mathrm{~mm}$.

Parent austenite carbon content estimate was calculated according to Eg. 1. giving $0.67 \%$ for SSF iron. According to ThermoCalc calculation for this alloy and with austenitisation temperature of $950{ }^{\circ} \mathrm{C}$ the equilibrium carbon content would be $0,78 \%$. Phase fractions and phase lattice constants for austempered samples measured with XRD are summarized in Table 3. As expected, the fraction of austenite increases as the austempering temperature is increased but also the lattice parameter of austenite increases which indicates higher carbon content of the austenite phase as Eq. 2 shows. Dependencies seem linear at this temperature range, although limitations of fitting a line through only three points is acknowledged. There is some variation in ferrite lattice parameter, and it did not behave in a linear manner as phase fractions and austenite lattice parameter did.

Table 3. X-ray diffraction study results. Phase fractions of ferrite $(\alpha)$, austenite $(\gamma)$ and lattice parameters of those.

\begin{tabular}{|l|c|c|c|c|c|}
\hline Material & $\mathrm{T}_{\text {aust }}\left[{ }^{\circ} \mathrm{C}\right]$ & $\mathrm{f}_{\alpha}[\%]$ & $\mathrm{f}_{\gamma}[\%]$ & $\mathrm{a}_{\alpha}[\AA$ a $]$ & $\mathrm{a}_{\gamma}[\mathrm{a}]$ \\
\hline GJS 500-7 & 310 & 61.8 & 38.2 & 2.8639 & 3.6293 \\
\hline GJS 500-14 & 270 & 94.3 & 5.7 & 2.8635 & 3.6212 \\
\hline GJS 500-14 & 300 & 74.1 & 25.9 & 2.8629 & 3.6255 \\
\hline GJS 500-14 & 330 & 58.5 & 41.5 & 2.8633 & 3.6287 \\
\hline
\end{tabular}

Silicon concentration maps were created with EDS. Resulting maps are shown in Figure 3. Blue round shapes in left lower and right upper corner are graphite nodules, and for the matrix the blueish color on the scale is 0 and red at the end of the scale $3.5 \%$. Silicon is more evenly distributed in silicon SSF iron compare do the conventional ferritic-pearlitic ductile iron grade. 

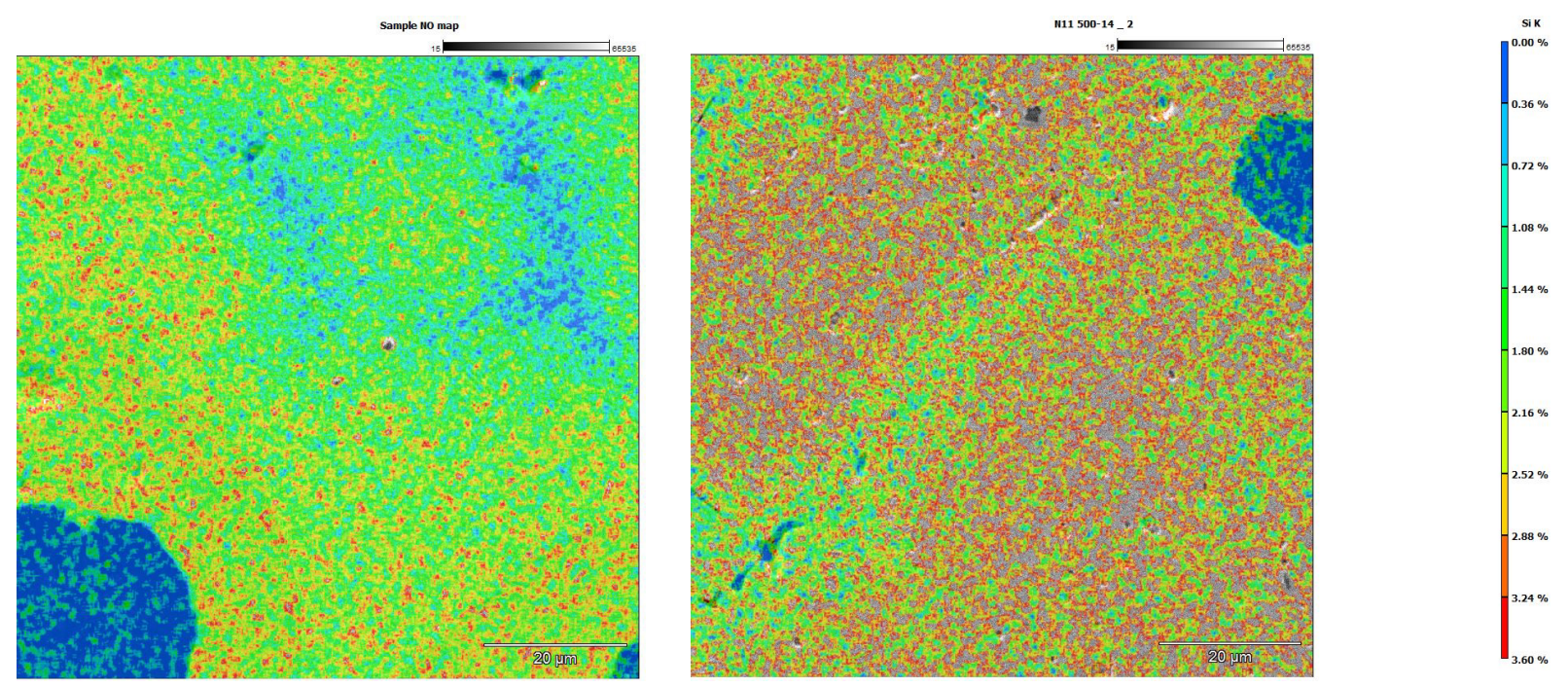

Figure 3. EDS mapping of silicon of reference and experimental material.

\section{Discussion}

Tensile test results showed overall high strengths and test bars maintained ductility. According to European norm EN 1564:2011 EN-GJS-1400-1 grade ADI should have a minimum tensile strength of $1400 \mathrm{MPa}, 0.2 \%$ proof strength of $1100 \mathrm{MPa}$ and elongation of $1 \%$. It can be seen from the results that the silicon solution strengthened quality achieves these mechanical values with seven to eight-fold elongation despite the suboptimal graphite structure. The strengths are on similar or higher level compared to the results presented for conventional silicon concentration ADI austempered in similar temperatures $[1,2,12]$. The current results match well with gained previously with silicon solution strengthened austempered ductile irons despite the difference in austenitisation temperature [7,9].

While machining the heat treated tensile test specimen great difficulties were observed with machinability of the samples despite the machinist was experienced with ADI. Many tool inserts were destroyed and there were challenges to obtain good surface quality due to vibrations. The material behaved as it was work hardening to larger extent than conventional ADI.

In austemperability experiments the first non-ausferritic phase to appear into the structure was pearlite due to high carbon content of the structure. The hardening depth was lower than expected and compared to literature [1]. Results were non-linear as $30 \mathrm{~mm}$ test bar was fully ausferritic yet $35 \mathrm{~mm}$ test bar showed pearlite already at $7 \mathrm{~mm}$ depth. This can have been due to unsuccessful quenching of the test bar in laboratory scale equipment although also discussions with experienced heat treatment workshop representative supported this phenomenon in cases of incomplete hardening.

XDR is a bulk analysis method and it averages the results over the sample surface. Ferrite lattice parameter of SSF iron had some unexpected variance and is larger than anticipated when compared to the research published by Huyan et al while that of conventional grade fits data well [11]. When comparing the conventional and SSF grade iron, similar phase fractions lead to different mechanical properties SSF ADI being stronger. As with increasing austempering temperature both austenite fraction and carbon content increased, it is suggested that there were some carbides forming during austempering because of same austenitisation the parent austenite carbon content was assumed to be same and its diffusion to graphite should have been easiest in highest austempering temperature but it still shows highest austenite fraction and carbon content.

Segregation of different alloying elements during solidification of ductile iron is well known and thus the silicon is not evenly distributed in the structure. However, according to EDS analysis, silicon is more evenly distributed in SSF iron than in conventional grade iron and concentration evens out as alloying is increased. Austempering heat treatment cycles are not long enough to cause significant change in these segregation patterns and resulting ausferrite will inherit the segregation 
pattern. This is likely to influence the carbon content of the resulting ausferrite and possibly thus reducing the mechanical stability of it.

\section{Conclusions}

As in previously published research, it was possible to produce austempered ductile iron from unalloyed silicon solution strengthened ductile iron. SSF ADI seems to have higher strength compared to conventional ADI with similar heat treatments and phase fractions. SSF ADI was markedly harder to machine in heat treated state compared to conventional ADI. In austemperability experiments it was not possible to through harden the $35 \mathrm{~mm}$ cross-section. First non-ausferritic structure to appear was pearlite.

\section{References}

[1] E. Dorazil, High strength austempered ductile cast iron. Prentice Hall, 1991.

[2] M. Johansson, Austenitic- Bainitic Ductile Iron, Trans. Am. Foundry Soc. 85 (1977) 117-122.

[3] L.-E. Bjorkegren, K. Hamberg, B. Johannesson, Mechanical properties and machinability of Sisolution-hardened ferritic ductile iron, Trans. Am. Foundrymen's Soc. 104 (1996) 139-145.

[4] L. Sidjanin, D. Rajnovic, O. Eric, R. E. Smallman, Austempering Study of Unalloyed and Alloyed Ductile Irons, Mater. Sci. Technol. 26 (5) (2010) 567-571.

[5] Z. Ławrynowicz, S. Dymski, Carbon Concentration of Austenite in Austempered Ductile Iron (ADI), Arch. Foundry Eng. 7 (3) (2007) 93-99.

[6] H. Nieswaag, J. W. Nijhof, Influence of Silicon on Bainite Transformation in Ductile Iron; Relation to Mechanical Properties, in The Physical Metallurgy of Cast Iron, 1984, vol. 34, no. 1, pp. 411-422.

[7] A. Kochański, A. Krzyńska, T. Radziszewski, Highsilicone Austempered Ductile Iron, Arch. Foundry Eng. 14 (1) (2014) 55-58.

[8] R. C. Voigt, C. R. Loper, Austempered Ductile Iron-Process Control and Quality Assurance, J. Mater. Eng. Perform. 22 (4) (2013) 2776-2794.

[9] A. Krzyńska, A. Kochański, Properties and Structure of High-Silicone Austempered Ductile Iron, Arch. Foundry Eng. 14 (2) (2014) 91-94.

[10]R. Larker, Austempered Ductile Iron, Method for Producing This and Component Comprising, Patent EP2092089A4.

[11]F. Huyan, R. Larker, P. Rubin, Effect of Solute Silicon on the Lattice Parameter of Ferrite in Ductile Irons, ISIJ Int. 54 (1) (2014) 248-250.

[12]E. Puustinen, Enhancing the Mechanical Properties of Solid Solution Strengthened Ferritic Spheroidal Graphite Cast Iron with Austempering Heat Treatment, Aalto University, 2015. 